\title{
Performance Levels of RC Structures by Non-Linear Pushover Analysis
}

\author{
Rakesh Yadav*, Dr. Trilok Gupta** and Dr. Ravi Kr. Sharma*** \\ * (M.Tech student, Department of Civil Engineering, College of Technology and Engineering, MPUAT, \\ Udaipur, Email: rakeshyadav1927@gmail.com) \\ ** (Assistant Professor, Department of Civil Engineering, College of Technology and Engineering, MPUAT, \\ Udaipur) \\ *** (Professor, Department of Civil Engineering, College of Technology and Engineering, MPUAT, Udaipur)
}

\begin{abstract}
In the recent earthquakes in which many concrete structures have been severely damaged or collapsed, have indicated the need for evaluating the seismic adequacy of existing buildings. About $60 \%$ of the land area of our country is susceptible to damaging levels of seismic hazard. We can't avoid future earthquakes, but preparedness and safe building construction practices can certainly reduce the extent of damage and loss. In order to strengthen and resist the buildings for future earthquakes, the behavior of a building during earthquakes depends critically on its overall shape, size and geometry. The nonlinear pushover analysis is becoming a popular tool for seismic performance evaluation of existing and new structures. The weak zones in the structure can be examined by conducting this push over analysis and then it will be decided whether the particular part is to be retrofitted or rehabilitated according to the requirement. This method determines the base shear capacity of the building and performance levels of each part of building under varying intensity of seismic force. The results of effects of different plan on seismic response of buildings have been presented in terms of displacement, base shear and plastic hinge pattern
\end{abstract}

Keywords: Pushover analysis, Seismic performance, Performance level, Target displacement, Lateral load patterns.

\section{INTRODUCTION}

The earthquake is the vibration of the earth's surface that follows a sudden release of energy in the crust. Ground surface moves in all directions during earthquake. The most devastating effects on buildings are caused by lateral movements which disturb the stability of the structure, leading to collapse sideways. Since buildings are normally constructed to resist gravity loads, many conventional systems of construction are not inherently resistant to horizontal forces. Strengthening of such buildings have been proved as more economical and viable immediate shelter solution rather than replacement of buildings [1].

Pushover analysis has been the preferred method for seismic performance evaluation of structures by the major rehabilitation guidelines and codes, because it is computationally and conceptually simple. Pushover analysis allows tracing the sequence of yielding and failure of member and structural level and also tracing of the progress of overall capacity curve of the structure [7].

Pushover analysis is a series of incremental static analysis carried out to develop a capacity curve for the building. A target displacement which is an estimate of the global displacement of the structure is determined based on capacity curve, the extent of damage occurrences by the building when subjected to design level ground shaking. Since the behavior of reinforced concrete structures might be highly inelastic under seismic loads, the global inelastic performance of RC structures would be dominated by plastic yielding effects and consequently the accuracy of the pushover analysis would be influenced by the ability of the analytical models to capture this effect [8].

The purpose of the pushover analysis is to evaluate the expected performance of a structural system by estimating its strength and deformation demands in design earthquakes by means of a static inelastic analysis, and comparing these demands to available capacities at the performance levels. The evaluation is based on an assessment of important performance parameters, including global drift, inter-story drift, and inelastic element deformations (either absolute or normalized with respect to a yield value), deformations between element's, and element and connection forces (for elements and connections that cannot sustain inelastic deformations). The inelastic static pushover analysis can be viewed as a method for predicting seismic force and deformation demands, which accounts in 
an approximate manner for the redistribution of internal forces occurring when the structure is subjected to inertia forces that no longer can be resisted within the elastic range of structural behavior [12].

A limit state of damage which may be considered satisfactory for a given building and a given ground motion intensity is known as a performance level. It contains structural and non structural performance levels consider the substantial damage within the building, the safety hazard and the post-earthquake serviceability of the building [14].

In particular, the seismic rehabilitation of older concrete structures in high seismicity areas is a matter of growing concern, since structures venerable to damage must be identified and an acceptable level of safety must be determined. To make such assessment, simplified linear-elastic methods are not adequate. Thus, the structural engineering community has developed a new generation of design and seismic procedures that incorporate performance based structures and are moving away from simplified linear elastic methods towards a more non linear technique [15].

\section{PERFORMANCE LEVELS OF THE STRUCTURES}

Pushover curve is a graphical representation between base shear along vertical axis and roof displacement along horizontal axis. Performance point of the structure in various stages can be obtained from pushover curve. The various performance levels for a building are expressed in terms of a base shear carried versus roof displacement curve as shown in Fig. 1. The range $\mathrm{AB}$ is elastic range, $\mathrm{B}$ to $\mathrm{IO}$ is the range of immediate occupancy IO to LS is the range of life safety and LS to $\mathrm{CP}$ is the range of collapse prevention. When a hinge reaches point $\mathrm{C}$ on its force displacement curve that hinge must begin to drop load. If all the hinges are within the $\mathrm{CP}$ limit then the structure is still said to be safe. On the contrary, if the hinges formed are beyond CP limit then it is said that the structure collapses. There are five levels of global structural response depending on the permissible amount of damage suffered by the structure when push-over analysis is performed [9].

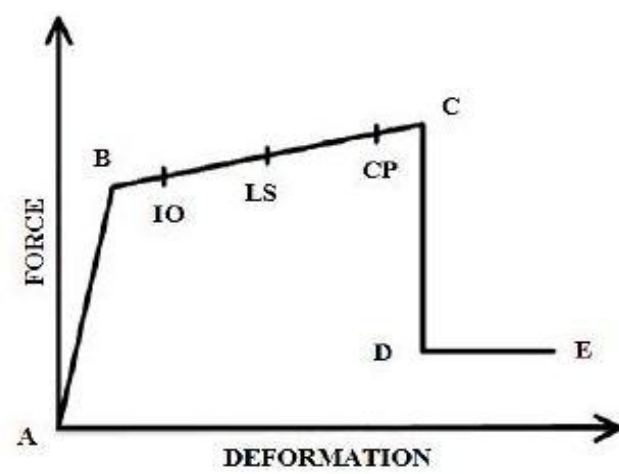

Fig. 1 Typical pushover curve with acceptance criteria [9]

Where,

$\mathrm{IO}=$ Intermediate Occupancy

LS $=$ Life Safety

$\mathrm{CP}=$ Collapse Prevention

Point ' $A$ ' corresponds to the unloaded condition.

Point ' $B$ ' corresponds to the onset of yielding.

Point ' $C$ ' corresponds to the ultimate strength.

Point ' $D$ ' corresponds to the residual strength. For the computational stability, it is recommended to specify non-zero residual strength beyond $\mathrm{C}$. In absence of the modeling of the descending branch of a load versus deformation curve, the residual strength can be assumed to be $20 \%$ of the yield strength.

Point ' $E$ ' corresponds to the maximum deformation capacity with the residual strength. To maintain computational stability, a high value of deformation capacity is assumed [9].

\subsection{Operational Level (OL)}

In the Operational level, the following facts can occur in the structure. egligible structural and nonstructural damage. ccupants are safe during event.

tilities are available.

acility is available for immediate re-use.

osses less than 5\% of replacement value [17].

\subsection{Immediate Occupancy Performance Level (IO)}

Structural performance level, immediate occupancy, means the post-earthquake damage state in which only very limited structural damage has occurred. In this occupancy performance, the risk of life injury and structural damage is very low, and although some minor structural repairs may be appropriate. In the immediate occupancy level, the following facts can occur in the structure; 
egligible structural damage

-

ccupants are safe during event

inor nonstructural damage

$\bullet$

uilding is safe to occupy but may not function

-

imited interruption of operations

osses less than $15 \%$ [17].

\subsection{Life Safety Performance Level (LS)}

Structural performance level life safety means the post-earthquake damage state in which significant damage to the structure has occurred, but some margin against either partial or total structural collapse remains. Some structural elements and components are severely damaged, but this has not resulted in large falling debris hazards, either within or outside the building. Injuries may occur during the earthquake; however, it is expected that the overall risk of life-threatening injury as a result of structural damage is low. It should be possible to repair the structure; however, for economic reasons this may not be practical. in this level, the following fact can occur in the structure;

-

ignificant structural damage

ome injuries may occur

$\bullet$

xtensive nonstructural damage

$\bullet$

uilding not safe for re-occupancy until repaired

osses less than $30 \%$ [17].

\subsection{Collapse Prevention Performance Level (CP)}

Structural performance level, collapse prevention, means the building is on the verge of experiencing partial or total collapse. Substantial damage to the structure has occurred, potentially including significant degradation in the stiffness and strength of the lateral force resisting system, large permanent lateral deformation of the structure and to more limited extent degradation in vertical-loadcarrying capacity. However, all significant components of the gravity load resisting system must continue to carry their gravity load demands. Significant risk of injury due to falling hazards from structural debris may exist. The structure may not be technically practical to repair and is not safe for reoccupancy, as aftershock activity could induce collapse. In this level, the following fact can occur in the structure; xtensive (near complete) structural and nonstructural damage

ignificant potentialdior injury but not wide scale loss of life

- $\quad B$

xtended loss of use

- $\quad$ L

epair may not be practical

- $\quad \mathrm{L}$

osses greater than $30 \%$ [17].

\section{TARGET DISPLACEMENT}

The target displacement serves as an estimate of the global displacement of the structure is expected to experience in a design earthquake. It is the roof displacement of the structure. In the pushover analysis it is assumed that the target displacement for the MDOF (Multi degree of freedom) structure can be estimated as the displacement demand for the corresponding equivalent SDOF (Single degree of freedom) system transformed to the SDOF (Single degree of freedom) domain through the use of a shape factor. The target displacement is intended to represent the maximum displacement likely to be experienced during the design earthquake. The target displacement, $\delta_{\mathrm{t}}$ is determined using the esfiation given below [19].

$$
\begin{gathered}
\square_{\mathrm{t}}=\mathbf{C}_{0} \mathbf{C}_{1} \mathbf{C}_{2} \mathbf{C}_{3} \mathbf{S}_{\mathrm{a}}\left[\mathbf{T e}^{2} / \mathbf{2} \square^{2}\right] \mathrm{g} \\
\text { Where, }
\end{gathered}
$$

$\mathbf{T}_{\mathrm{e}}=\mathrm{T}_{\mathrm{i}}\left(\sqrt{ } \mathrm{K}_{\mathrm{i}} / \mathrm{K}_{\mathrm{e}}\right)$

$\mathbf{C}_{\mathbf{0}}$ is modification Efactor to relate spectral displacement of an equivalent SDOF (Single degree of freedom Bsystem to roof displacement of the building MDOF (Multi degree of freedom) system. L

$\mathbf{C}_{\mathbf{1}}$ is modification factor to relate expected inelastic displacements to displacements for linear elastic response.

$\mathbf{C}_{2}$ is modification factor to represent the effect of pinched hysteretic shape, stiffness degradation and strength deterioration on maximum displacement response.

$\mathbf{C}_{3}$ is modification factor to increased displacements due to P- $\Delta$ effects.

$\mathbf{S}_{\mathbf{a}}$ is response spectrum acceleration at the effective fundamental period and damping ratio.

$\mathrm{g}$ is acceleration of gravity.

$\mathrm{T}_{e}$ is effective fundamental period of building in the direction under consideration [19].

\section{LATERAL LOAD PATTERNS}

For a performance level evaluation, the load pattern selection is likely to be more critical than accurate determination of the target displacement. The load patterns are intended to represent and bound, the distribution of inertia forces 
in design earthquake. it is clear that the distribution of inertia forces will vary with the time and severity of the earthquake. If invariant load patterns are used than the distribution of inertia forces will be reasonably constant throughout the earthquake and maximum deformations obtained when the structure response is not severely affected by higher mode effects and when the structure detected under single load yielding mechanism. One should be uniform load pattern (story forces proportional to story masses), which emphasizes the demands in lower stories compared to the demands in upper stories and magnifies the relative importance of story shear forces compared to the overturning moment. Other load pattern is derived from SRSS story shears [12].

\section{SEISMIC PERFORMANCE OF RC BUILDINGS BY PUSHOVER}

\section{ANALYSIS}

Alashker et al. [1] analyzed the effects of building configuration on seismic performance of RC buildings by pushover analysis. They examined four buildings in zone III with different plans of aspect ratio of 1, 1.5, 2 and 4 having the overall plan dimensions are $20 \mathrm{~m} \times 20 \mathrm{~m}, 25 \mathrm{~m} \times 16 \mathrm{~m}, 28.5 \mathrm{~m} \times$ $14 \mathrm{~m}$ and $40 \mathrm{~m} \times 10 \mathrm{~m}$ having same area of $400 \mathrm{~m} 2$. The buildings are five-story with height of $15.2 \mathrm{~m}$. Columns and beams sizes are $500 \times 300 \mathrm{~mm}$. The results are compared in terms of base shear, displacement and plastic hinge pattern to evaluate the effects of different plan aspect ratio on the performance level of buildings. They found maximum base shear has been found in case 4 (building plan area $40 \mathrm{~m} \times 10 \mathrm{~m}$ with plan aspect ratio of 4) however, case 2 (building plan area $25 \mathrm{~m} \times 16$ $\mathrm{m}$, with plan aspect ratio of 1.5 ) shows the least value of base shear in $\mathrm{X}$ - direction and $\mathrm{Y}$ - directions. Moreover, displacement value has been found same in first three cases except the case 4 where results show the maximum displacement in $\mathrm{X}$-direction. Also they observed the number of hinges (formed at different levels of performance of building) increases with increase in plan aspect ratio.

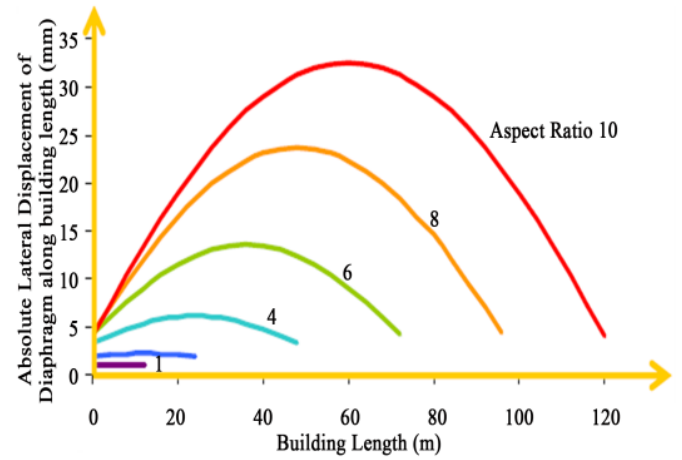

Fig. 2 Lateral displacement of diaphragm [1]

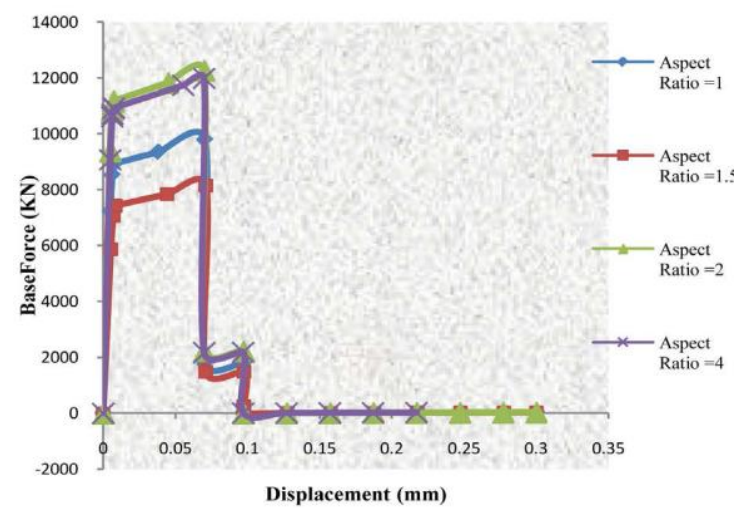

Fig. 3 Comparison between base force and displacement in $\mathrm{X} \& \mathrm{Y}$-directions. [1]

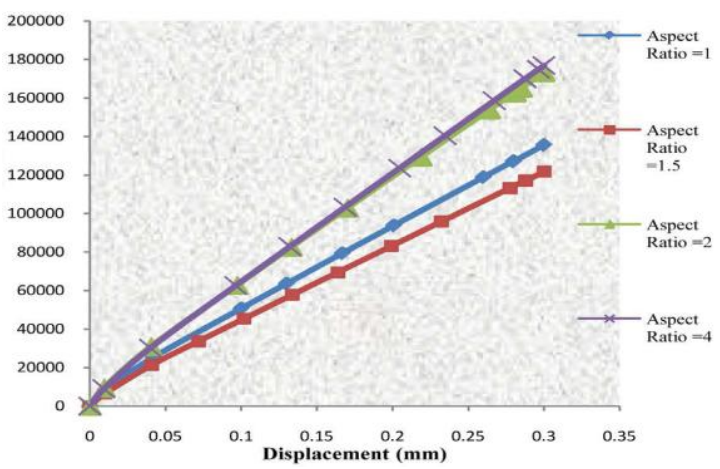

Fig. 4 Comparison between base force and displacement in $\mathrm{X} \& \mathrm{Y}$-directions. [1]

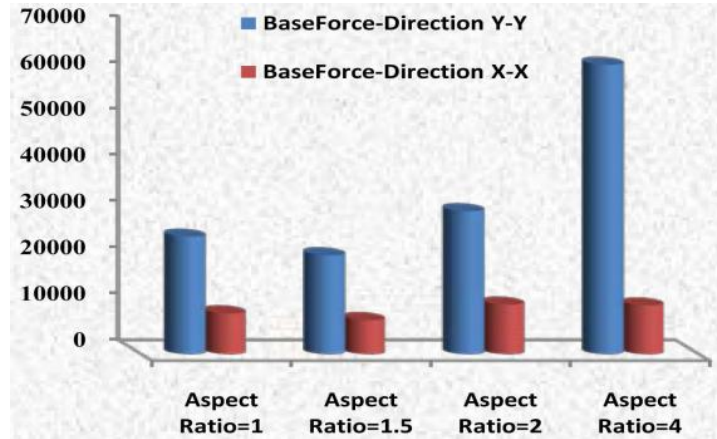

Fig. 5 Comparison of base forces in X \& Ydirections. [1]

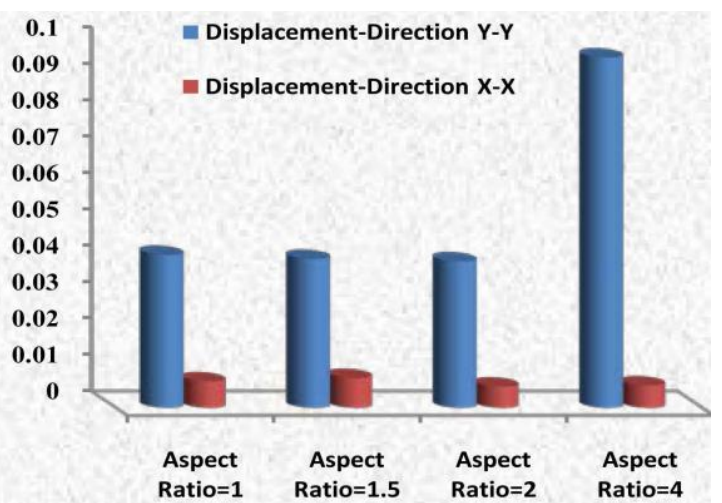


Fig. 6 Comparison of displacement in X \& Ydirections. [1]

Kalibhat et al. [9] analyzed the seismic performance of RC frames with vertical stiffness irregularity from pushover analysis. They examined six models of 4-bay with $5 \mathrm{~m}$ spacing and 4-storey with $2.5 \mathrm{~m}$ height 2-D RC frames for zone III \& V. They treated model-1 as a benchmark frame as there is no vertical irregularity in it and the degree of vertical irregularity is increased from model 2 to model 6. They observed the point of intersection between response capacity curve and demand capacity curve known as performance point of the structure also observed the performance point shifts with different zones that indicate the vulnerability of the structures in the form of severity of plastic hinge formation. The plastic hinge formation increases from model 2 to model 6 wherein the frame becomes more and more asymmetric in elevation. This indicates that the asymmetry in elevation of the building increases the severity of lateral forces on the buildings.

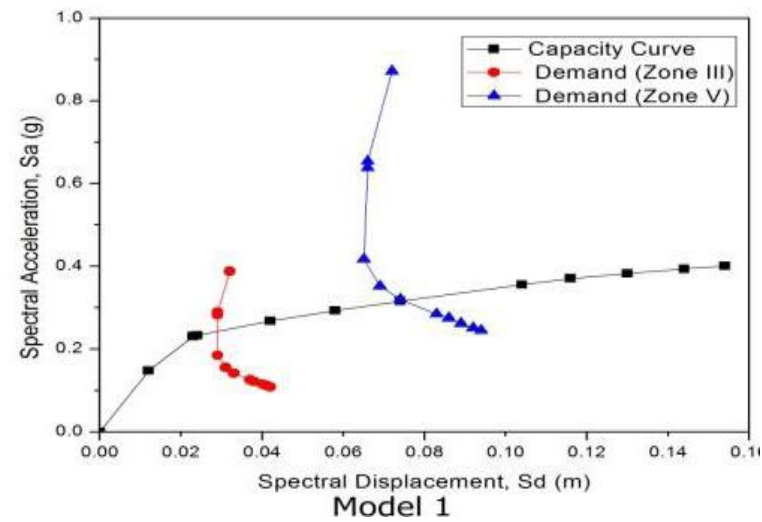

Fig. 7 Performance point of model-1 [9]

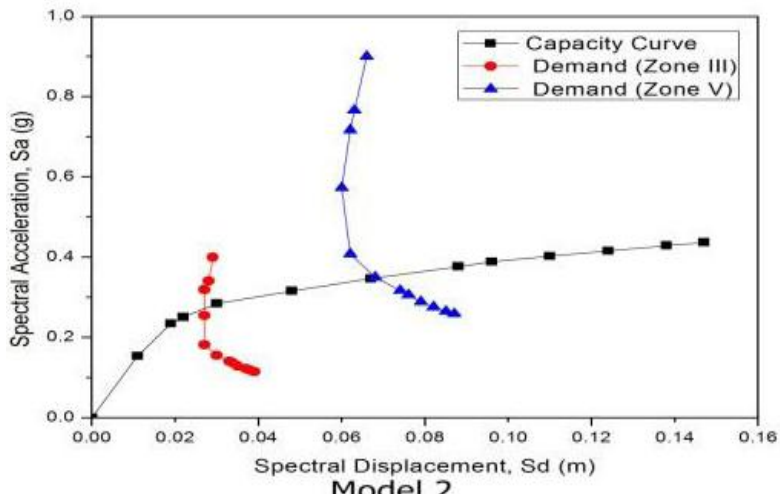

Fig. 8 Performance point of model-2 [9]

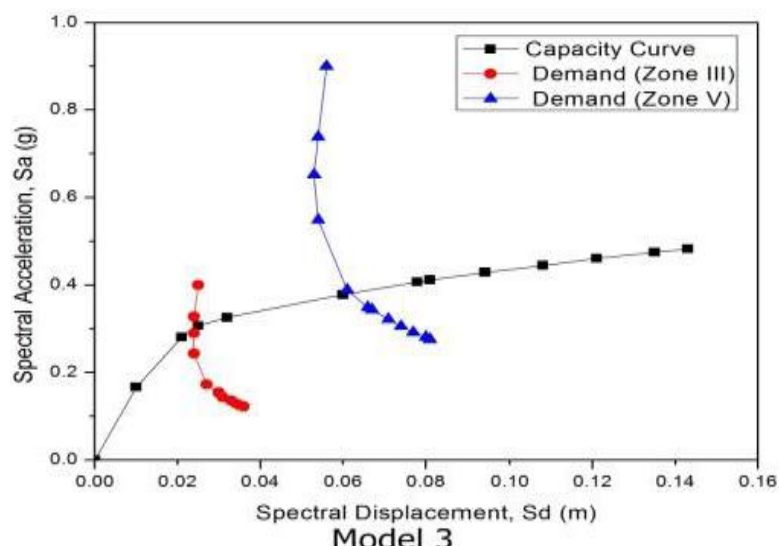

Fig.9 Performance point of model-3 [9]

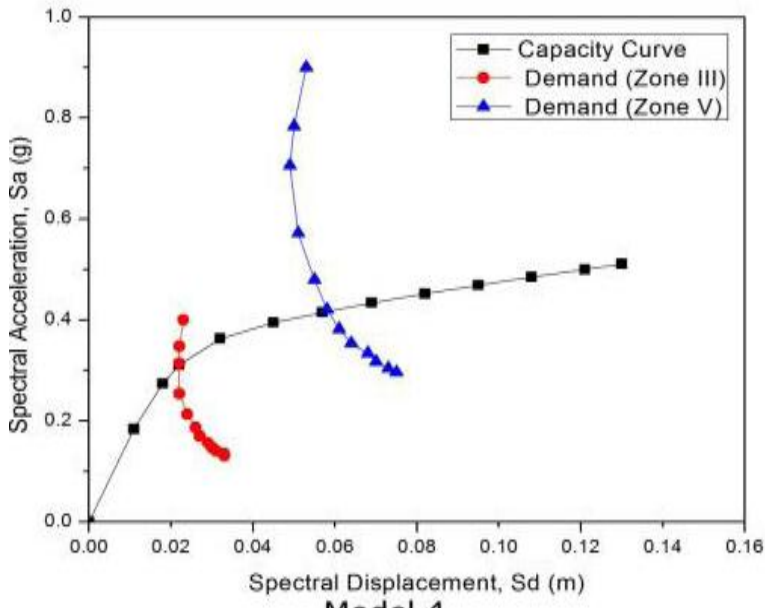

Model 4

Fig. 10 Performance point of model-4 [9]

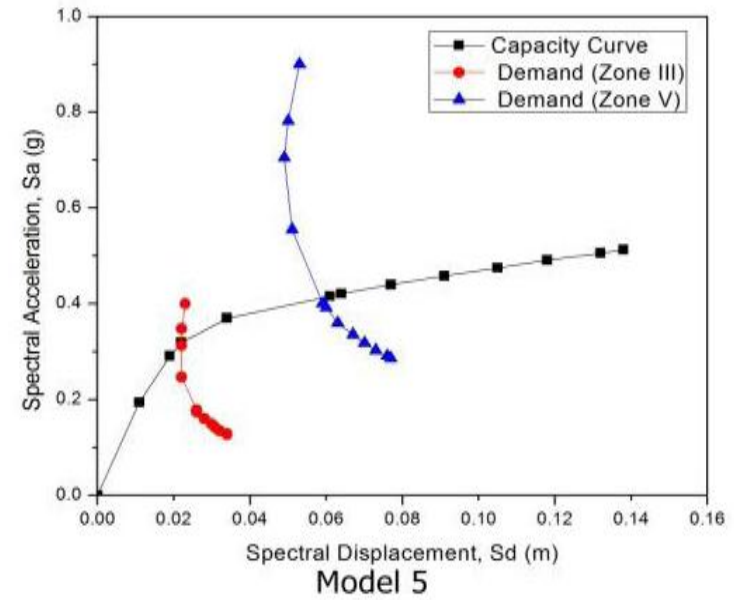

Fig. 11 Performance point of model-5 [9] 


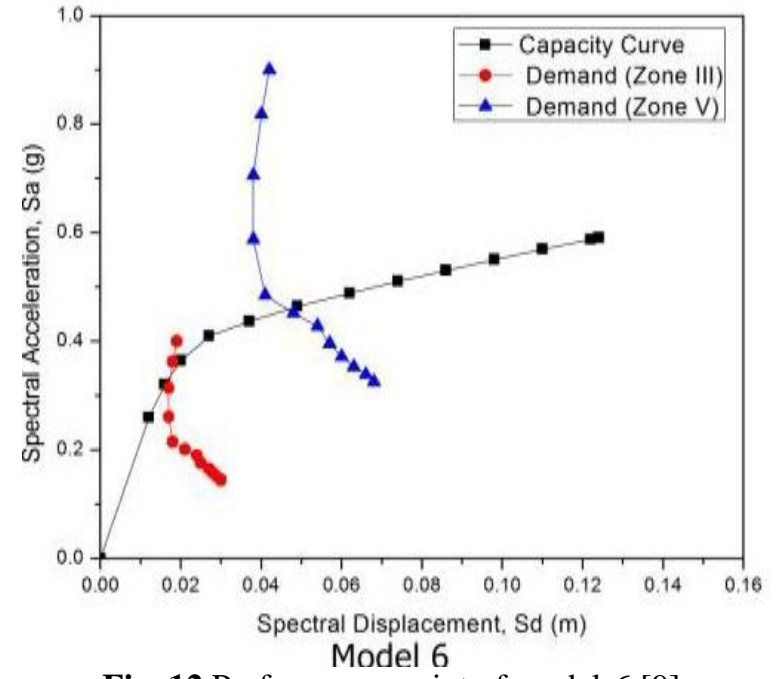

Fig. 12 Performance point of model-6 [9]

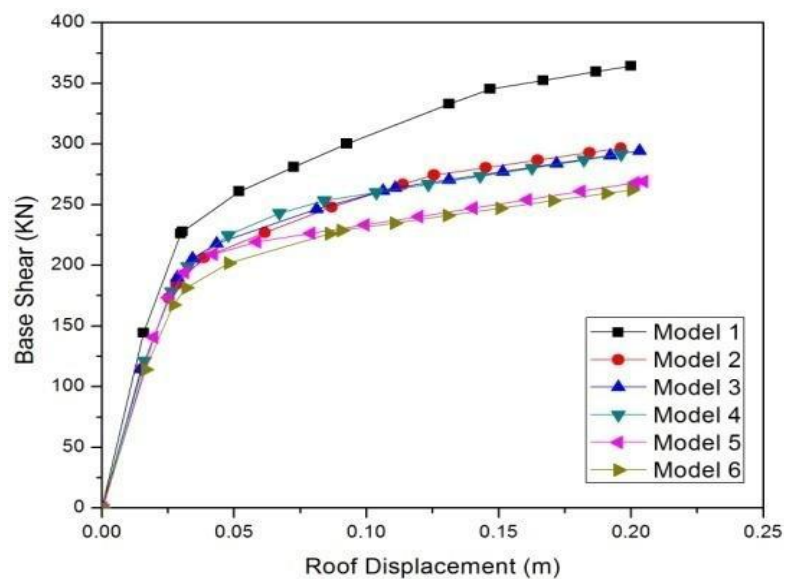

Fig. 13 Pushover curves for the six frame models [9]

Naik et al. [16] conducted seismic performance evaluation of reinforced concrete frames with irregular elevations using nonlinear static pushover analysis. Multi storey reinforced concrete frames with irregular elevation subjected seismic loads are taken. Irregularity in elevation was introduced in terms of percentage reduction in height such as $20 \%, 40 \%$ and $60 \%$. The frame was designed as per guidelines of IS 456:2000. Based on the obtained results, it was concluded that as the percentage of irregularity in elevation increases the base shear decreases, thus reducing the lateral load carrying capacity of the structure. Hence utmost care should be taken by the structural engineers while designing the irregular structure. There is significant decrease in performance of structure in respect of responses such as lateral displacement, storey drift, and storey, though the deformation is increasing due to formation of collapse mechanism. The analysis shows that, the seismic performance is very much dependent on the mass, stiffness, strength regularity and ductile or non-ductile behavior.
Prashant and Kori [19] analyzed the seismic response of $\mathrm{RC}$ frame building (27 degree sloped with ground) with soft storey. They analyzed G+9 storey's building of plan dimension $35 \mathrm{~m} \times 35 \mathrm{~m}$ with a floor to floor height of $3.5 \mathrm{~m}$ and designed for gravity loads only are evaluated for seismic load combination as per IS: 1893-2002. The buildings found to be inadequate in carrying the seismic load combination. The non- ductile MRF (Moment resisting frame) buildings of $\mathrm{G}+9$ storey's satisfying the gravity load combinations are analyzed by pushover analysis methods, it is observed that the natural time periods obtained from the code are less than that of analysis results and their variation is shown in Fig. 14 and 15. The time period and base shear of Model 1 is $137 \%, 118 \%, 110 \%, 96 \%$, $134 \%, 113 \%$ and also $362 \%, 269 \%, 276 \%, 230 \%$, $319 \%$, 240\% more than that of Model 2, Model 3, Model 4, Model 5, Model 6 and Model 7 respectively.

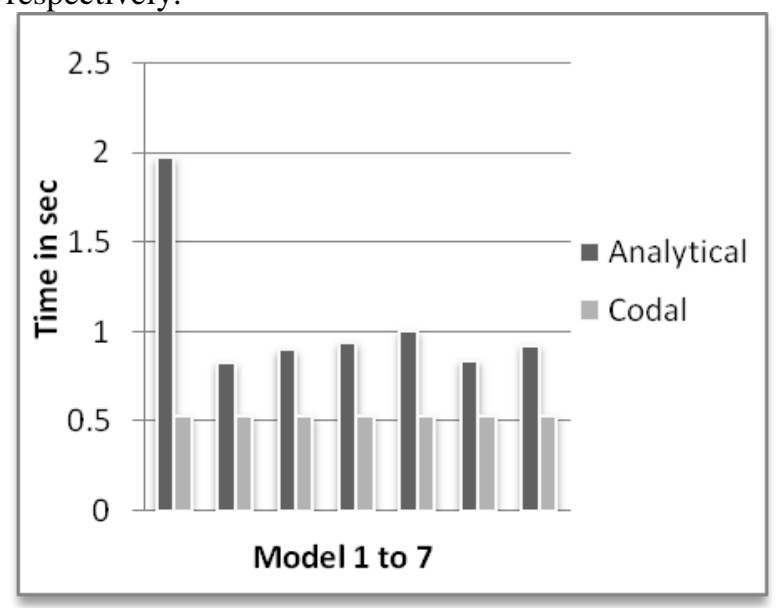

Fig. 14 Time period of models [19]

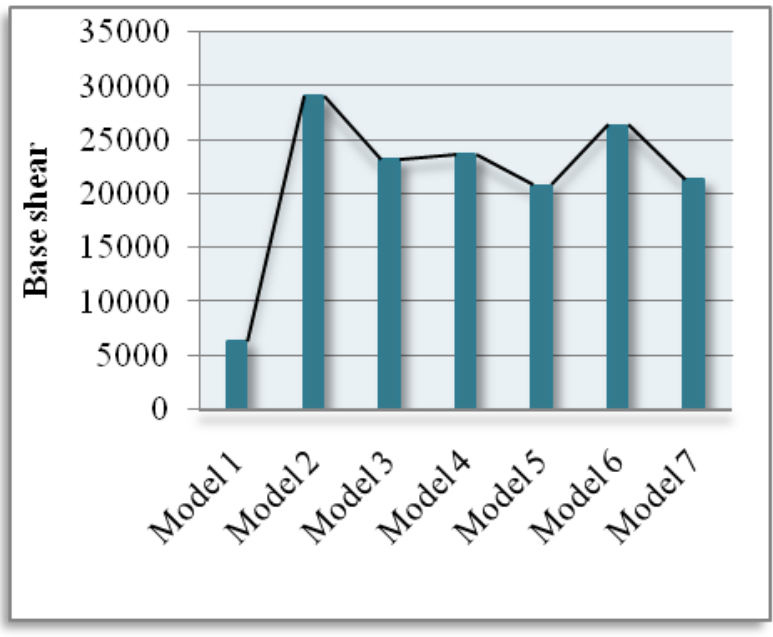

Fig. 15 Base shear of models [19] 
Prashant and Kori [19] evaluated hinge statuses at failure modes. As the buildings are less stiff along X-direction, when building pushed in the Push-X direction more number of hinges are formed. Along Y-direction for Push-Y the hinges formed in all models are in the range of IO-LS, also It is observed that the number of hinges formed at target displacement level in soft storey 4 \& 5 model, are in $>\mathrm{E}$ range, but the two fully infilled models and two corner infill models reduces these hinges to D-E range as shown in Table 1.

Table 1 Hinge status at target displacement [19]

\begin{tabular}{|c|c|c|}
\hline Model & $\begin{array}{c}\text { Displacement } \\
(\mathbf{m m})\end{array}$ & $\begin{array}{c}\text { Hinge } \\
\text { status }\end{array}$ \\
\hline Model-1 & 203 & $>\mathrm{E}$ \\
\hline Model-2 & 102 & D to E \\
\hline Model-3 & 108 & D to E \\
\hline Model-4 & 107 & $>\mathrm{E}$ \\
\hline Model-5 & 120 & $>\mathrm{E}$ \\
\hline Model-6 & 103 & D To E \\
\hline Model-7 & 112 & D to E \\
\hline
\end{tabular}

\section{SUMMARY}

The use of non-linear pushover analysis has been broadly investigated in recent years. This review paper has presented aspects of static pushover analysis promises to be a useful and effective tool for performance levels of the structure, which could be summarized and concluded as [1]

1. The building with plan aspect ratio 1.5 shows the least base shear in both directions, thereafter base shear significantly increases with increase in plan aspect ratio [1].

2. Increasing plan aspect ratio makes the $Y$ direction of building more vulnerable to damage during earthquake [1].

3. By increasing plan aspect ratio, the total number of hinges formed at different performance levels also increases, which may lead to building deficiency of resisting seismic loads [1]

4. Structure becomes vulnerable with increase in vertical irregularity [9].

5. With increase in vertical irregularity the percentage of plastic hinges crossing elastic limit increase, rendering the structure more vulnerable [9].

6. Vulnerability of the structure depends on the Zone in which structure is located. Therefore utmost care should be taken while designing irregular structure in high earthquake prone regions [9].

7. The storey drift of soft storey is effectively minimized by adding masonry infill walls in the ground storey [15].

8. From the study it is concluded that, the plastic hinges are more in case of bare frame model, where the stiffness of walls are neglected and also the plastic hinges are more in the soft storey building when it is compared with full infill or corner infill models. This is because of lack of stiffness in the ground storey of the building [15].

9. The lateral displacements of the soft storey shows the abrupt change in the displacement profile at storey 1 , which indicates the stiffness irregularity due to soft storey mechanism and increases vulnerability towards seismic forces [15].

10. Time period for bare frame model is almost 90 to 135 percent more, when compared to other models [19].

11. The base shear of infill models is almost 250 percent more when compared to bare frame model [19].

\section{REFERNCES}

[1] Alashker, Y. Nazar, S. and Ismail M. (2015). Effects of building configuration on seismic performance of $\mathrm{RC}$ buildings by pushover analysis, Open Journal of Civil Engineering 5(1): 203-213.

[2] Akbari, R. \& Maheri, R. (2013). Analytical investigation of response modification (behavior) factor, for reinforced concrete frames rehabilitated by steel chevron bracing, Structure and Infrastructure Engineering 9(6): 507-515.

[3] BIS, IS 1893: Part 1 (2002).Criteria for earthquake resistant design of structures part1 general provisions and buildings, Fifth revision, Bureau of Indian Standard.

[4] BIS, IS 456: (2000). Plain and reinforced concrete code of practice, fourth revision, Bureau of Indian Standard.

[5] Computers and Structures, 2001 SAP (2000). Three dimensional static and dynamic finite element analysis and design of structures, Computers and Structures Inc., Berkeley.

[6] Dhadve, P., Rao, A. Rupanvar, A. Deokate K. Admile P.R. and Nemade P. D.(2015). Assessment of P-delta effect on high rise buildings, International Journal on Recent and Innovation Trends in Computing and Communication 3(5): 3231-3236.

[7] Girgin, P. and Darılmaz, K. (2007). Seismic Response of Infilled Framed Buildings Using Pushover Analysis. Department of Civil Engineering, Istanbul Technical University, 54(5)

[8] Kadid, A. and Boumrkik, A. (2008). Pushover analysis of reinforced concrete frame structures, Asian Journal of Civil Engineering (Building and Housing) 9(1):75-83.

[9] Kalibhat, M.G., Kumar Y.M. Kamath. K. and Prasad .S.K. (2014), Seismic performance of R.c. frames with vertical stiffness irregularity 
from pushover analysis, IOSR Journal of Mechanical and Civil Engineering 61-66.

[10] Khan, G. and Vyawahare, M.R. (2013). Push over analysis of tall building with soft stories at different levels, International Journal of Engineering Research and Applications (IJERA) 3(4): 176-185.

[11] Khandve, V. (2012).Seismic response of RC frame buildings with soft storey, International Journal of Engineering Research and Applications (IJERA) 2(3):2100-2108.

[12] Krawinkler H., Seneviratna, G.D.P.K. (1998). Pros and cons of a pushover analysis of seismic performance evaluation, Engineering Structures 20(4): 452-464.

[13] Mahesh, S. and Rao, P. (2014). Comparison of analysis and design of regular and irregular configuration of multi Story building in various seismic zones and various types of soils are using ETABS and STAAD, IOSR Journal of Mechanical and Civil Engineering (IOSR-JMCE) 11(6): 45-52.

[14] Manjula, N.K., Nagarajan, P. And Madhavan Pillai, T.M.(2013). A comparison of basic pushover methods, International Refereed Journal of Engineering and Science (IRJES) 2(5):14-19.

[15] Maske, A. A., Maske, N. A. and Shiras, P. (2014). Pushover analysis of reinforced concrete frame structures. International Journal of Advanced Technology in Engineering and Science 2(10):118-128.

[16] Naik, S.B., Zameeruddin, M., Saleemuddin, M., and Sangle, K.K., (2015), Seismic Performance Evaluation of Reinforced Concrete Frames with Irregular Elevations using Nonlinear Static Pushover Analysis, International Journal of Modern Trends in Engineering and Research 7(2):648-653.

[17] Phyo, A. P. and Khaing, S.Y. (2014). Investigation on performance levels of 8storey rc building with pushover analysis, International journal of Scientific engineering and technology research 3(11): 2533-2541.

[18] Prabhu, T.A. (2013). Seismic evaluation of 4story reinforced concrete structure by nonlinear static pushover analysis, Bachelor of Technology Thesis, National Institute of Technology Rourkela.

[19] Prashant, D. And Kori, J.G. (2013). Seismic response of one way slope $\mathrm{RC}$ frame building with soft storey, International Journal of Emerging Trends in Engineering and Development 5(3):311-320.

[20] Sonwane, D.P. and Ladhane, K.B. (2015), Seismic performance based design of reinforced concrete buildings using nonlinear pushover analysis, International Journal of
Engineering Research \& Technology (IJERT) 4(6):1110-1116 